\title{
Learning Organization and its Effect on strategic success: Analysis of Private Institutions of Erbil Higher Education
}

\section{Basne Farooq Jabbar}

Department of Business Administration, Collage of Business Administration and Economics, Lebanese French University, Erbil, Kurdistan, Iraq

Basne3@yahoo.com

\section{Prof. Dr. Ahlam Ibrahim Wali}

Department of Business Administration, Collage of Business Administration and Economics, University of Salahaddin, Erbil, Kurdistan, Iraq

ahlam.wali@su.edu.krd

\section{ARTICLE INFO}

\section{Article History:}

Received: $15 / 4 / 2021$

Accepted: 24/5/2021

Published: Spring 2021

\section{Keywords:}

Organizational

learning, Knowledge

Management,

Knowledge Integration,

Team cooperation,

Private Universities,

Strategic.

Doi:

10.25212/Ifu.qzj.6.2.39

\section{ABSTRACT}

To determinate the role of organizational learning across project-based organizations, this study applies a micro-level perspective of organizational learning theory to the social constructivist approach to address relational learning information collaboration that takes into account a strategic perspective involving the development of collective knowledge. The sample was distributed to 180 individuals from different targeted private universities from a total population of 1400 private universities that operate through collaborative ventures to test the research hypotheses. We were able to use 168 surveys in our statistical study after deleting 12 surveys with incorrect responses. Furthermore, value building continues to play a role in bridging the gap between corporate development and long-term strategic growth. Furthermore, exploratory purpose shows a major mediation function in inter-organizational learning, as well as the potential to sustain long-term partnerships with partners, as a beneficial result of partner diversity as a moderate factor. Information convergence was shown to be strongly linked for strategic achievement, as was corporate culture, competences and capabilities, and team cooperation 


\section{Introduction}

Over the last decade, the organizational learning literature has been greatly enriched and extended by assessing and analyzing different elements and phenomena that affect this social behavioral method (Alomran, 2019). The first approaches to organizations' distinguishing learning process summarize it as entrepreneurial teamwork between a group or pairs of organizations (Annosi, et al., 2020) and as external learning (Lane, 2001). These contributions were an approach to add interorganizational learning as a fourth level to the concept of organizational learning. Thanks to available IT technology, networking, corporate responsibility, and global ethics, external networking, resources have been much more open than ever before. Learning and developing expertise through organized events and cooperation with collaborators including sponsors, collaborating institutions, education agencies, governments, and service centers, among others. Via the structural and process approaches to relational learning, can be represented in many forms and techniques such as networking, training, alliances, tailor-made responses to challenges, and many other me-mechanism mechanisms. As a result, these knowledge exchange activities can lead to realized planned and unplanned experiences and capacity building from private universities. Furthermore, diverse methods and viewpoints that reflect the multidimensional construction of interorganizational learning can be explored (Aspeling \& Mason, 2020). Collaborative learning about knowledge acquisition can be studied from two perspectives: strategic perspectives with more formalities and structured objectives, and knowledge acquisition perspectives with less formality (Bahrami, et al., 2016). We stress the team learning approach and, more precisely, the conceptual viewpoint, which requires more formalities and organized objectives than the knowledge transfer perspective, based on organizational learning literature.

Organizational learning refers to organizations' participation in collaborations and/or interorganizational networks in which multiple collaborators with legally distinct yet technically based characteristics collaborate on information (Birasnav, et al., 2019). Project-based organizations are one of the processes that better represents the 
convergence of organizations found in various fields, but not in private universities, according to the literature (Bratnicki \& Dyduch, 2020).

In a conventional mechanistic approach to management, organizational learning structure is listed under the modern approach to management, which entails dealing with time-limited tasks instead of defined roles. When an organization struggles to accomplish particular goals and when complexities control the governing system (Ejodame \& Oshri, 2018), as is evident in the partnership with private universities, an operational learning framework is more fitting. Traditional organizational models are mostly based on hierarchical structures that include organizational roles with individual workers, while organizational learning seeks to identify ways to better execute programs within a given budget in environments where portfolio, strategic, program, and project management are all in place. Levels are fully immersive in order to finish the project on time, on budget, and with high consistency (Eniola, et al., 2019). Project management is apparent in private universities in operation, but the literature on corporate governance ignores the presence of many private universities that serve as operational learning institutions. Local and national private universities all over the world are attempting to capitalize on their relationships with foreign citizens' social organizations and other collaborators by creating strategic connections that require knowledge sharing, allowing them to discuss potential creative acts. On the other hand, international civil society organizations, providers, and sponsors strive to accomplish their objectives and provide appropriate resources in areas where they are required, usually by local and national private universities. Thus, through the execution of collaborative ventures, state, national, and international private universities strengthen their offer of efficient services (Gauriot \& Page, 2019).

\subsection{Research problem and Research Questions:}

The problem of this research can be summarized in the main question and other subquestions raised as the foundation of this research project:

- Do the organizational learning consequences in metropolitan areas with a pluralistic structure presidency and legislative and legal structure have the same circumstances and outcomes as regular statements? 
- Does the role of the path of organizational learning partnerships play in improving universities' capacity to establish links with internal and external stakeholders in order to achieve long-term strategic sustainability in these areas?

- How does the legal environment in which foreign and local private universities exist help this process succeed in these areas?

- How can the organizational learning research inspire management of private universities to pursue an exploratory goal of creating meaning in the face of partner diversity?

\subsection{The Aim of the Research}

The research's main goal is to look into the role of organizational learning capability in achieving strategic goals in a few companies in Kurdistan, especially in Erbil.

\subsection{The Significance of the Research}

Organizational learning is closely linked to the field of organizational learning, which views it as a dynamic mechanism that mostly emerges from cooperation between various organizations (Martinsuo, 2019). Organizational learning has been extensively researched from various viewpoints and in various countries with varying environmental conditions, but collaboration between private universities and the position of legal and regulatory bodies have not received enough attention in these discussions (Morcillo-Bellido, 2019). To the best of the authors' understanding, the mechanism in autonomous regions for building the capacity of local communities to operate sustainably with limited external feedback from stakeholders has not been explored. Several previous studies have connected organizational learning to a variety of outcomes and has analyzed it in depth (Pabico, et al., 2019). Information cooperation in partnerships, networks, joint ventures, and their outcomes at various organizational levels have been the subject of recent research on knowledge exchange and collaboration. The learning literature confirms the possibility of creating new knowledge required for innovation and creating synergies between partners (Pillai, et al., 2020), and the literature on organizational networks and 
policies explained role in achieving a critical position in the relationship (Pillai, et al., 2020). (Prasetya, 2017).

\subsection{Research Objectives}

The research's main goals can be found in a variety of places: The importance of organizational learning as a medium for learning exchange is first established in local and national private universities, as well as international partners. Second, it is critical to maintain collaborative learning relationships between the various private universities in the Helsinki metropolitan area, which bear witness to the legal and regulatory conflicts arising from the duality of the rules governing private universities in the Autonomous Communities, as well as its role in improving the capacity of private universities in these regions. Third, the effect of the legal and regulatory system of the Autonomous Communities on the relationship between knowledge cooperation and capability building is assessed. Finally, comprehend the effect of the partners' traits reflected in the variety of partners on the relationships between learning process and the company's plan to seek the desired knowledge in order to generate value. 


\section{QALAAI ZANISTSCIENTIFIC JOURNAL}

A Scientific Quarterly Refereed Journal Issued by Lebanese French University - Erbil, Kurdistan, Iraq

Vol. (6), No (2), Spring 2021

ISSN 2518-6566 (Online) - ISSN 2518-6558 (Print)

\subsection{Research Model}

Independent Variables

$\underline{\text { Dependent Variables }}$

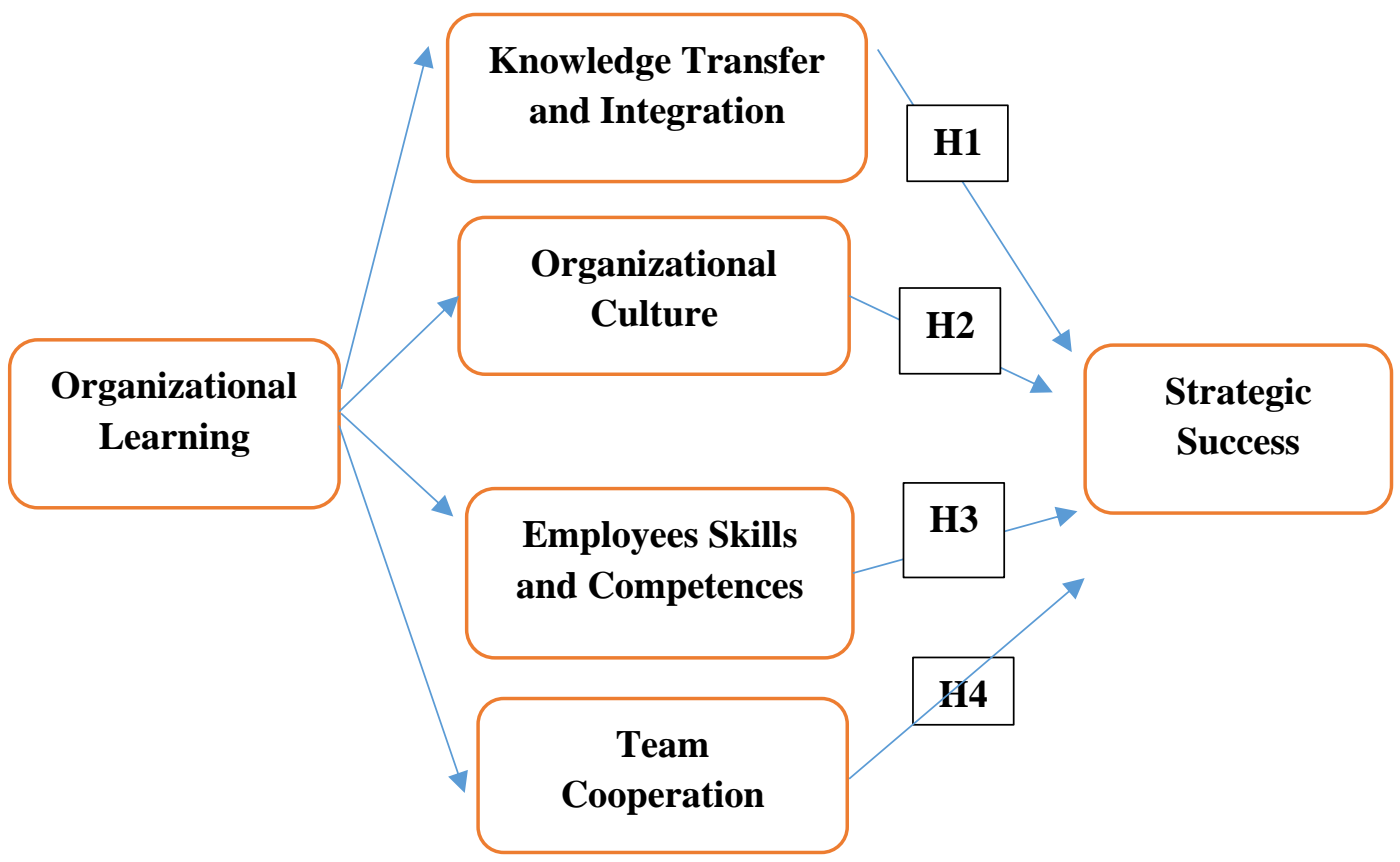

Figure (1): Research Model

Source: (Annosi, et al., 2020). 


\subsection{Research Hypotheses}

This research has several hypotheses, which are the following:

First research Hypothesis: Knowledge Integration significantly associated with strategic success.

Second research Hypothesis: Organizational culture significantly associated with strategic success.

Third research Hypothesis: Competences and skills significantly associated with strategic success.

Fourth research Hypothesis: Team cooperation significantly associated with strategic success.

\section{Literature Review and Theoretical Background}

Today's interdependent phenomena (Schniederjans, et al., 2020), organizational learning is one of the most critical mechanisms and a fundamental way of extending an organization's expertise and capabilities. It refers to the contribution of two or more organisations to the mutual accumulation of knowledge (Schniederjans, et al., 2020). (Shahar, et al., 2019). Organizational coaching has been studied in many areas of industry and has a variety of benefits and drawbacks in each. Alliances have the majority of the organizational philosophy literature, in which they explain the knowledge sharing resources open to mutual and interconnected collaborators, but they have only been able to resolve tensions relating to data security in two opposing ways (Valdez-Juárez, et al., 2019). Furthermore, before Wang, et al., (2020), proposed two aspects into two sides of the coin and generalized the notion of two-way learning in relationships to include all aspects simultaneously, knowledge sharing and security were considered as two initial businesses in a few studies. They were able to prove scientifically that these two factors had a substantial effect on an organization's strategic growth. The collaborative effectiveness of coalition teams (interorganizational groups) will significantly affect the acquisition of intelligence through strategic partnerships, where their strategic thinking and leadership capabilities can enhance long-term strategic success prospects and greater information collaboration (Waqas, et al., 2019). While researchers and practitioners agree that robust 
formalization will work, gaining information between the coordinating parties contributes to both formal and informal learning habits, both of which have a favorable connection to organizational learning. a difficulty in studying (Zhang \& Zhu, 2019).

The impact of collaboration on information sharing, knowledge transfer, and sense exchange has been studied more and more in the literature in an effort to discover its consequences across different and web-based infrastructures (Alomran, 2019). They discovered a connection between various facets of relational learning and teamwork, but the growth of the value of shared knowledge, which is dependent on the collaborating teams' competencies, the quality of shared information reflected in IT capacities, IT management, and management support (Annosi, et al., 2020). Networks are entities in which various organisations collaborate, coordinate, and support one another at the network level to accomplish network-level objectives in a cooperative fashion. The learning process at the network level typically enables the organisations participating with those networks to understand how to compete and perform (Aspeling \& Mason, 2020). While organizations' individual efforts to gain advanced, external expertise can exist, collective work may increase their work practices for creativity and better strategic performance, according to several reports (Bahrami, et al., 2016). Birasnav et al. (2019) present the findings of a study of Spanish tourism firms, arguing that companies that participate in multiple interorganizational relationships are more effective in achieving radical innovation and bringing value to their services. Project management at private universities necessitates ongoing communication with sponsors and stakeholders in order to discover daily office changes. In this case, correspondence is normally done in writing or by some technological means (Bratnicki \& Dyduch, 2020). Project management necessitates the availability of a variety of talents, with people in those organizations performing a variety of activities. This condition can result in failed projects because of private universities rushing into projects that are incompatible with their methods or available skills (Chen, et al., 2018). Organizational learning has been linked to the strategic success of different systems, organizational, and individual levels of organizations in various sectors, and several studies have not only looked at the 
significant impact of collaborative relationships on the delivery of existing knowledge, but also on the creation of new and improved embedded organizations' opportunities to transfer knowledge (Chepsergon, et al., 2020).

\subsection{Organizational Collaboration and Strategic Tensions}

Organizational learning literature has specifically demonstrated the importance of articulated shredded programs in achieving strategic advantages in product creation (Danish, et al., 2020), service development (Ejodame \& Oshri, 2018), management roles, capability and expertise (Eniola, et al., 2019), and other areas. In addition to all of the IOP benefits stated in the literature, it faces fundamental obstacles such as deep collaboration and communication between the players concerned (Gauriot \& Page, 2019), strategic policy barriers (Hagemeister \& Rodrguez-Castellanos, 2019), and legal and regulatory barriers (Hagemeister \& Rodrguez-Castellanos, 2019). (Husain, et al., 2016). Because of the participation of several actors of diverse expertise and regulatory contexts, organizational learning is distinguished by entirely inconsistent processes (Kasuganti, 2017). Knein, et al., (2020) discuss the most common reasons that cause organizations to retreat from inter-organizational cooperation and particularly from horizontal networks, despite the fact that the literature has attempted to elucidate the significant benefits of cross-border interaction. Individualism and opportunism, as well as a lack of membership selection requirements, lack of confidence, loyalty issues, and individualism and opportunism. Furthermore, the aforementioned misunderstandings trigger temporary conflicts between the parties concerned, necessitating serious "time control" mechanisms from policymakers, as well as better use of border crossing points to handle interventions. By smoothing the boundaries between the partners involved by temporal comprehension and confrontations, and reduces the effect of such tensions (Lin, et al., 2019).

\subsection{Enabling trust and accountability in institutions}

For decades, the literature on corporate governance has emphasized hierarchical relationships enshrined in formal and social control systems (processes, laws, regulations, norms, and principles that regulate action against organizational or 
shared goals) in order to preserve and frame the form of relationships with partners (Prasetya, 2017). When trust was first discussed in the literature, it was as a framework for collaboration and self-interest, until Ruy \& Alliprandini, (2017) established and operationalized it as a fundamental mechanism for governance (Schniederjans, et al., 2020). Computational and relational approaches have been used to study the regulation of inter-organizational interactions and the trust literature (Shahar, et al., 2019).

The degree of reciprocal trust between working partners has a significant impact on engagement and consistency in a collaborative partnership. Furthermore, the mutual interaction between transaction characteristics (interorganizational relationships dependent on relationship-specific agreements, such as asset specificity) and relationship characteristics (natural interaction between various parties in both) has an impact on confidence. Members will meet to discuss the relationship of the chosen partners. Portfolios, credibility, reputation shadow of the past, as well as the expected benefits for the partnership referred to as the preview of the future), as well as through mutual support and interaction between the organization (management experience and skills that enhance the efficiency of the organization and enable it to manage currency risks, as well as their alternative options to choose between the $p$ and the p), as well as through mutual support and interaction between the organization (the management experience and skills that enhance the efficiency of the organization and enable it to manage currency risks, as well as their alternative options to Conversely, owing to environmental factors or the unstable and volatile existence of human activities in response to different triggers (Wang, et al., 2020), joint collaborators can be faced with residual threats that cannot be anticipated or mitigated by continuing participation. Instead of using the 'computational approach to managing interorganizational relationships suggested in the reciprocal interaction, partners may want to embrace the risks of trade as a means of resolving complexity differences (Waqas, et al., 2019).

\subsection{Organizational Learning and Strategic Success}

Organizational learning is one of the protections for preserving relationships, especially for those without bargaining power (Zhang \& Zhu, 2019). The 
organizational learning literature has clearly demonstrated the importance of rag initiatives articulated in organizational learning in gaining competitive advantages in product creation (Alomran, 2019), service development (Annosi, et al., 2020), management feature improvement, ability and knowledge improvement (Aspeling \& Mason, 2020), and other areas. Many studies have shown that learning from social organizations and education organizations can help organizations provide better care, especially in the health sector (Bahrami, et al., 2016). The ontological distinction between state health institutions and CSOs specialized in the provision of such services, according to Birasnav et al. (2019), the latter being able to alleviate the problems encountered in state health systems, particularly in poorer welfare states (Chen, et al., 2018). Previous research has found that private universities exert oppressive pressure on the firm partners with which they collaborate due to competing interests (Chepsergon, et al., 2020). However, this notion has been challenged, with private universities being seen as sources of information if they have common interests, such as corporate social responsibility, and can enhance the creed (Colman, 2020). Humanitarian aid provided by civil society organizations, especially local and national private universities, in areas in need is difficult and time-consuming to handle on an individual basis, and demands significant integration efforts on which these organizations' operations as non-profit organizations depend (Danish, et al., 2020).

\section{Research Methodology}

\subsection{Research Design}

This research contains the execution of previous research in many important topics relating to buildings in general analysis in order to better understand the introduced topics and shape a guide to further research. At private universities (Lebanese French University, Tishk International University, Knowledge University, Cihan University, Bayan University, and Catholic University) in Erbil, a researcher used a quantitative approach to evaluate the developed research hypothesis and assess the importance of organizational learning in achieving and maintaining company strategic accomplishment. 


\subsection{Sample Size and Data Collection Instruments}

The reciprocal partnerships between private universities and supporters, promoters, funders, and support centers were the focus of this study's research. A questionnaire was used to gather data for this analysis. The survey was created using scales from previous experiments to create a questionnaire. Local and private colleges with project-based organization structures are included in this study's community, who mostly organize their organizational and leadership operations to carry out tasks in such a way that the workforce of various divisions of various roles is led by a project manager required to carry out the project (Ejodame \& Oshri, 2018).

The sample was distributed to 180 main individuals in different targeted private universities from a total population of 1400 private universities who carry out their operations through collaborative ventures to validate the study hypotheses. To avoid the biases that plague most experiments, the questionnaire was sent out at random to private colleges that work together on a collaborative initiative of a different focus. Furthermore, private universities with local and national operational levels only participate in our sample to eliminate high non-response rates and increase the validity of study results, as both species work in the same regional environment, for comparisons between allow them and be useful notwithstanding international private universities that do not consider representative cases (Eniola, et al., 2019). We were able to use 168 surveys in our statistical review after deleting 26 surveys with incorrect responses.

\subsection{Measurements}

Organizational learning was assessed in this analysis by implementing and changing a scale used by Gauriot \& Page, (2019) that was originally used by Hagemeister \& Rodrguez-Castellanos, (2019), Li (2006). The relationship component of the index built for capacity building was used in the analysis for capacity building. Although the elements used to quantify these variables are extracted from Kasuganti's philosophical and theoretical research, sustained Strategic progress has been achieved by applying the knowledge first provided in a study reviewed by Husain, et 


\section{QALAAI ZANISTSCIENTIFIC JOURNAL \\ A Scientific Quarterly Refereed Journal Issued by Lebanese French University - Erbil, Kurdistan, Iraq}

Vol. (6), No (2), Spring 2021

ISSN 2518-6566 (Online) - ISSN 2518-6558 (Print)

al., (2016). The exploratory aim was accepted (Knein, et al., 2020). The scale of partner dissimilarity was adapted from (Lin, et al., 2019).

\section{Data Analysis}

\subsection{Demographic Analysis}

Table (1): Geographic Analysis

\begin{tabular}{|c|c|c|c|}
\hline Items & Scales & Frequency & Percent \\
\hline \multirow{3}{*}{ Gender } & Male & 76 & 52.1 \\
\cline { 2 - 4 } & Female & 70 & 47.9 \\
\hline \multirow{3}{*}{ Age } & $30-40$ & 45 & 30.8 \\
\cline { 2 - 4 } & $41-50$ & 60 & 41.1 \\
\cline { 2 - 4 } & $51-60$ & 38 & 26.0 \\
\cline { 2 - 4 } & 60 and above & 3 & 2.1 \\
\hline \multirow{4}{*}{ Education } & Master & 94 & 64.4 \\
\cline { 2 - 4 } & Ph.D. & 48 & 32.9 \\
\cline { 2 - 4 } & Others & 4 & 2.7 \\
\hline
\end{tabular}

Source: (By author, SPSS Version 23, 2021)

Table (1) demonstrates participants' demographic analysis, starting with participants' gender. It was found that the majority of participants were male who participated in this study, as for participants age, it was found that the majority of participants were from 41 years old to 50 years old, and as for participants' education, it was found that the majority of participants had master degree.

\subsection{Reliability Analysis}

Table (2): Reliability of Knowledge Transfer and Integration

\begin{tabular}{|l|l|}
\hline Questions & Alpha \\
\hline Top management integrates information from different organizational areas & .751 \\
\hline The organization transmits a clear sense of future direction to employees. & .732 \\
\hline $\begin{array}{l}\text { Employees have access to the data that they need to perform my job in an efficient } \\
\text { and effective manner. }\end{array}$ & .776 \\
\hline The organization is always seeking to develop new answers. & .719 \\
\hline The organization is quick to provide assistance for development of new ideas. & .745 \\
\hline The organization is open and receptive to new ideas. & .752 \\
\hline The organization puts new knowledge learnt in training and education into practice. & .785 \\
\hline We are always first to launch new services. & .768 \\
\hline The organization hires highly specialized or knowledgeable personnel & .745 \\
\hline
\end{tabular}




\section{QALAAI ZANISTSCIENTIFIC JOURNAL}

A Scientific Quarterly Refereed Journal Issued by Lebanese French University - Erbil, Kurdistan, Iraq

Vol. (6), No (2), Spring 2021

ISSN 2518-6566 (Online) - ISSN 2518-6558 (Print)

Employees are keenly aware of where their knowledge can serve the organization

.767

Source: (By author, SPSS Version 23, 2021)

Table (2) demonstrates the reliability analysis of Knowledge Transfer and Integration. The researcher used 10 questions in order to measure Knowledge Transfer and Integration, however as it can be seen in the above table that all items used to measure Knowledge Transfer and Integration were reliable since the values were higher than 0.6.

Table (3): Reliability of Organizational Culture

\begin{tabular}{|l|l|}
\hline Questions & Alpha \\
\hline $\begin{array}{l}\text { The organization has basic culture and value that include learning as a key factor in } \\
\text { improvement of process and services. }\end{array}$ & .762 \\
\hline $\begin{array}{l}\text { The organizational culture takes large scale actions to achieve the objectives of the } \\
\text { organization. }\end{array}$ & .732 \\
\hline Organizational culture encourages employees for recommending new work ideas & .776 \\
\hline $\begin{array}{l}\text { The current organizational culture uses feedback from organization experiments } \\
\text { (such as surveys and trials of new methods) }\end{array}$ & .754 \\
\hline Organizational culture maintains a certain mix of skills among its pool of employees & .764 \\
\hline Employees make extensive use of information systems to support their work & .732 \\
\hline Management monitors important organizational performance variables & .774 \\
\hline Management removes obsolete information from employee access & .719 \\
\hline Management assigns employees to other parts of the organization for cross training & .756 \\
\hline Our employees resist changing to new ways of doing things & .772 \\
\hline
\end{tabular}

Source: (By author, SPSS Version 23, 2021)

Table (3) demonstrates the reliability analysis of organizational culture. The researcher used 10 questions in order to measure organizational culture, however as it can be seen in the above table that all items used to measure organizational culture were reliable since the values were higher than 0.6 .

Table (4): Reliability of Competences and Skills

\begin{tabular}{|l|l|}
\hline Questions & Alpha \\
\hline $\begin{array}{l}\text { The organization believes that employee learning is an investment, not a cost which } \\
\text { leads to achieve strategic success. }\end{array}$ & .747 \\
\hline $\begin{array}{l}\text { Since learning has been eliminated at the organization, we are compromising our } \\
\text { organization. }\end{array}$ & .768 \\
\hline
\end{tabular}




\section{QALAAI ZANISTSCIENTIFIC JOURNAL}

A Scientific Quarterly Refereed Journal Issued by Lebanese French University - Erbil, Kurdistan, Iraq

Vol. (6), No (2), Spring 2021

ISSN 2518-6566 (Online) - ISSN 2518-6558 (Print)

The organization's managers expect employees have adequate skills to be useful in problem solving.

We encourage use of original solutions when we deal with problems in the workplace.

.776

The skilled employees at the organization are always seeking for new and recent ways of dealing with problems.

Management assigns employees to other parts of the organization for cross training

Management learns new things about the organization by direct observation

There is formal data management function in the organization

The organization makes extensive use of electronic storage

Employees use electronic means to Communicate

.735

.768

742

759

.779

.746

.761

Source: (By author, SPSS Version 23, 2021)

Table (4) demonstrates the reliability analysis of competences and skills. The researcher used 10 questions in order to measure competences and skills, however as it can be seen in the above table that all items used to measure competences and skills were reliable since the values were higher than 0.6 .

Table (5): Reliability of Team Cooperation

\begin{tabular}{|l|l|}
\hline Questions & Alpha \\
\hline The team is involved in decision-making on which areas need improving. & .731 \\
\hline $\begin{array}{l}\text { The organization has team, resources, and equipment needed to develop new } \\
\text { services. }\end{array}$ & .746 \\
\hline Management team learn from the organization's partners & .774 \\
\hline Management team proactively addresses problems & .756 \\
\hline $\begin{array}{l}\text { Team encourages the use of frameworks and models to assist in decision- } \\
\text { making }\end{array}$ & .717 \\
\hline Top management integrates information from different organizational areas & .736 \\
\hline Management learns from the organization's partners & .749 \\
\hline Management ignores the strategies of competitors' top management & .728 \\
\hline Management learns new things about the organization by direct observation & .746 \\
\hline $\begin{array}{l}\text { Management uses feedback from organization experiments (such as surveys } \\
\text { and trials of new methods) }\end{array}$ & .755 \\
\hline
\end{tabular}

Source: (By author, SPSS Version 23, 2021)

Table (6): Reliability of Strategic Success

\begin{tabular}{|l|c|}
\hline Questions & Alpha \\
\hline The organization adopts a specific standardized strategy in its operations & .712 \\
\hline
\end{tabular}




\section{QALAAI ZANISTSCIENTIFIC JOURNAL}

A Scientific Quarterly Refereed Journal Issued by Lebanese French University - Erbil, Kurdistan, Iraq

Vol. (6), No (2), Spring 2021

ISSN 2518-6566 (Online) - ISSN 2518-6558 (Print)

\begin{tabular}{|l|l|}
\hline $\begin{array}{l}\text { Strategies of the Organization are always tuned to the objectives of the } \\
\text { Organization }\end{array}$ & .745 \\
\hline $\begin{array}{l}\text { The Vision, Mission and Values of the Organization are clear and are reflected } \\
\text { in all processes of the Organization }\end{array}$ & .791 \\
\hline $\begin{array}{l}\text { Staff of the Organization understand their role in achievement of strategy } \\
\text { objectives }\end{array}$ & .767 \\
\hline The strategy adopted has a positive impact on performance of the organization & .770 \\
\hline The organization s operational strategy is acceptable to all employees & .719 \\
\hline $\begin{array}{l}\text { The organization's strategy formulation process is in accordance with the } \\
\text { organization s mission, vision statement. }\end{array}$ & .764 \\
\hline $\begin{array}{l}\text { Adequate time is given for consultations and agreement during strategy } \\
\text { formulation }\end{array}$ & .785 \\
\hline $\begin{array}{l}\text { The changes brought about by the strategic plan have been explained and } \\
\text { understood by all }\end{array}$ & .774 \\
\hline The organization structure supports implementation of strategy activities & .765 \\
\hline
\end{tabular}

Source: (By author, SPSS Version 23, 2021)

Table (6) demonstrates the reliability analysis of strategic success. The researcher used 10 questions in order to measure strategic success, however as it can be seen in the above table that all items used to measure strategic success were reliable since the values were higher than 0.6.

\subsection{Testing Research Hypotheses}

\subsubsection{Testing First Research Hypothesis}

Table (7): Correlation analysis between strategic success and knowledge integration and transfer

\begin{tabular}{|l|l|l|l|}
\hline \multicolumn{4}{|c|}{ Correlations } \\
\hline \multicolumn{2}{|c|}{} & $\begin{array}{l}\text { Knowledge Transfer and } \\
\text { Integration }\end{array}$ & $\begin{array}{l}\text { Strategic } \\
\text { Success }\end{array}$ \\
\hline $\begin{array}{l}\text { Knowledge } \\
\text { Transfer and } \\
\text { Integration }\end{array}$ & Pearson Correlation & 1 & $.731^{* *}$ \\
\cline { 2 - 4 } & Sig.(2-tailed) & 168 & .000 \\
\cline { 2 - 4 } & $\mathrm{N}$ & $.731^{* *}$ & 168 \\
\hline \multirow{3}{*}{ Strategic Success } & Pearson Correlation & .000 & 1 \\
\cline { 2 - 4 } & Sig.(2-tailed) & 168 & 168 \\
\cline { 2 - 4 } & $\mathrm{N}$ & \\
\hline$* *$ Correlation is significant at the 0.01 level (2-tailed). & \\
\hline
\end{tabular}




\section{QALAAI ZANISTSCIENTIFIC JOURNAL \\ A Scientific Quarterly Refereed Journal Issued by Lebanese French University - Erbil, Kurdistan, Iraq}

Vol. (6), No (2), Spring 2021

ISSN 2518-6566 (Online) - ISSN 2518-6558 (Print)

Source: (By author, SPSS Version 23, 2021)

Table (7) demonstrates correlation analysis to measure the association between strategic success and knowledge integration and transfer, it was found that there is a strong association between strategic success and knowledge integration and transfer.

Table (8): Model Summary Between Strategic Success and Knowledge Integration and Transfer

\begin{tabular}{|l|c|c|c|c|}
\hline \multicolumn{5}{|c|}{ Model Summary } \\
\hline Model & $\mathrm{R}$ & R Square & Adjusted R Square & Std. Error of the Estimate \\
\hline 1 & $.631 \mathrm{a}$ & .641 & .674 & .26458 \\
\hline \multicolumn{6}{|l}{ a. Predictors: (Constant), Knowledge Transfer and Integration } \\
\hline
\end{tabular}

Source: (By author, SPSS Version 23, 2021)

As it can be seen in table (8), the value of $\mathrm{R}$ square is more than six this means that more than $64 \%$ of factors have been demonstrated.

Table (9): ANOVA between strategic success and knowledge integration and transfer

\begin{tabular}{|c|c|c|c|c|c|c|}
\hline \multicolumn{7}{|c|}{ ANOVA } \\
\hline \multicolumn{2}{|c|}{ Mode } & Sum of Squares & df & Mean Square & F & Sig. \\
\hline 1 & Regression & 31.015 & 1 & 36.524 & 456.1 & $.000 \mathrm{~b}$ \\
& & & & & 23 & \\
\cline { 2 - 7 } & Residual & 20.651 & 358 & .071 & & \\
\cline { 2 - 7 } & Total & 71.256 & 342 & & & \\
\hline
\end{tabular}

Source: (By author, SPSS Version 23, 2021)

The table (9) can be seen ANOVA analysis between transfer and integration of knowledge with strategic success. It was found that the value of $F$ was more than four hundred, this means that there is a strong association between transfer and integration of knowledge with strategic success. 


\section{QALAAI ZANISTSCIENTIFIC JOURNAL}

A Scientific Quarterly Refereed Journal Issued by Lebanese French University - Erbil, Kurdistan, Iraq

Vol. (6), No (2), Spring 2021

ISSN 2518-6566 (Online) - ISSN 2518-6558 (Print)

Table (10): Simple regression analysis between strategic success and transfer and integrate of knowledge

\begin{tabular}{|c|c|c|c|c|c|c|}
\hline \multicolumn{7}{|c|}{ Coefficients } \\
\hline & \multirow[t]{2}{*}{ Model } & \multicolumn{2}{|c|}{$\begin{array}{l}\text { Unstandardized } \\
\text { Coefficients }\end{array}$} & \multirow{2}{*}{$\begin{array}{c}\text { Standardized } \\
\text { Coefficients } \\
\text { Beta } \\
\end{array}$} & \multirow[t]{2}{*}{$\mathrm{t}$} & \multirow[t]{2}{*}{ Sig. } \\
\hline & & $\mathrm{B}$ & Std. Error & & & \\
\hline \multirow[t]{2}{*}{1} & (Constant) & .081 & .123 & & .547 & .493 \\
\hline & $\begin{array}{l}\text { Transfer and } \\
\text { integrate of } \\
\text { knowledge }\end{array}$ & .711 & .019 & .732 & 23.52 & .000 \\
\hline
\end{tabular}

Source: (By author, SPSS Version 23, 2021)

The table (10) can be seen the regression between transfer and integrate of knowledge with strategic success. As it can be seen in the above table the value of both $B$ and Beta are positive and more than 0.5 this indicated that there is a positive association between transfer and integrate of knowledge with strategic success.

\subsubsection{Testing Second Research Hypothesis}

Table (11): Correlation analysis between organizational culture and strategic success

\begin{tabular}{|c|c|c|c|}
\hline \multicolumn{4}{|c|}{ Correlations } \\
\hline \multirow{2}{*}{$\begin{array}{c}\text { Organizational } \\
\text { culture }\end{array}$} & $\begin{array}{c}\text { Organizational } \\
\text { culture }\end{array}$ & $\begin{array}{c}\text { Strategic } \\
\text { Success }\end{array}$ \\
\cline { 2 - 4 } & Pearson Correlation & 1 & $.741^{* *}$ \\
\cline { 2 - 4 } & Sig.(2-tailed) & 168 & .000 \\
\hline \multirow{2}{*}{\begin{tabular}{c} 
Strategic Success \\
\cline { 2 - 4 }
\end{tabular}} & Nearson Correlation & $.741^{* *}$ & 168 \\
\cline { 2 - 4 } & Sig.(2-tailed) & .000 & 1 \\
\cline { 2 - 4 } & $\mathrm{N}$ & 168 & 168 \\
\hline$* *$ Correlation is significant at the 0.01 level (2-tailed). \\
\hline
\end{tabular}

Source: (By author, SPSS Version 23, 2021)

The table (11) shows correlation analysis to measure the association between strategic success and organizational culture, it was found that there is a strong association between strategic success and organizational culture. 


\section{QALAAI ZANISTSCIENTIFIC JOURNAL}

A Scientific Quarterly Refereed Journal Issued by Lebanese French University - Erbil, Kurdistan, Iraq

Vol. (6), No (2), Spring 2021

ISSN 2518-6566 (Online) - ISSN 2518-6558 (Print)

Table (12): Model Summary between organizational culture and strategic success

\begin{tabular}{|c|c|c|c|c|}
\hline \multicolumn{5}{|c|}{ Model Summary } \\
\hline Model & $\mathrm{R}$ & $\mathrm{R}$ Square & Adjusted R Square & Std. Error of the Estimate \\
\hline 1 & .598 & .601 & .632 & .2758 \\
\hline \multicolumn{5}{|l}{ a. predictors (Constant), Organizational Culture } \\
\hline
\end{tabular}

Source: (By author, SPSS Version 23, 2021)

As it can be seen in table (12), the value of $R$ square is more than six hundred this means that more than $60 \%$ of factors have been demonstrated.

Table (13): ANOVA between organizational culture and strategic success

\begin{tabular}{|c|c|c|c|c|c|c|}
\hline \multicolumn{2}{|c|}{ Mode } & $\begin{array}{c}\text { Sum of } \\
\text { Squares }\end{array}$ & df & Mean Square & F & Sig. \\
\hline \multirow{2}{*}{1} & Regression & 41.052 & 1 & 42.365 & 598.52 & $.000 \mathrm{~b}$ \\
\cline { 2 - 7 } & Residual & 29.52 & 368 & .091 & & \\
\cline { 2 - 7 } & \multicolumn{2}{|l|}{ Total } & 71.52 & 399 & & \\
\hline \multicolumn{2}{|l|}{ a. Dependent Variable: Strategic Success } \\
\hline \multicolumn{2}{|l|}{ b. Predictors (Constant) Organizational Culture } \\
\hline
\end{tabular}

Source: (By author, SPSS Version 23, 2021)

The table (13) can be seen ANOVA analysis between organizational culture with strategic success. It was found that the value of $F$ was more than five hundred, this means that there is a strong association between organizational culture with strategic success.

Table (14): Simple regression analysis between organizational culture and strategic success

\begin{tabular}{|c|c|c|c|c|c|c|}
\hline \multicolumn{7}{|c|}{ Coefficients } \\
\hline & \multirow[t]{2}{*}{ Model } & \multicolumn{2}{|c|}{$\begin{array}{l}\text { Unstandardized } \\
\text { Coefficients }\end{array}$} & \multirow{2}{*}{$\begin{array}{c}\text { Standardized } \\
\text { Coefficients }\end{array}$} & \multirow[t]{2}{*}{$\mathrm{t}$} & \multirow[t]{2}{*}{ Sig. } \\
\hline & & $B$ & Std. Error & & & \\
\hline \multirow[t]{2}{*}{1} & (Constant) & .082 & .141 & & .498 & .785 \\
\hline & $\begin{array}{l}\text { Organizational } \\
\text { culture }\end{array}$ & .698 & .017 & .701 & 21.29 & .000 \\
\hline
\end{tabular}




\section{QALAAI ZANISTSCIENTIFIC JOURNAL \\ A Scientific Quarterly Refereed Journal Issued by Lebanese French University - Erbil, Kurdistan, Iraq}

Vol. (6), No (2), Spring 2021

ISSN 2518-6566 (Online) - ISSN 2518-6558 (Print)

Source: (By author, SPSS Version 23, 2021)

The table (14) can be seen regression between organizational culture with strategic success. As it can be seen in the above table the value of both $B$ and Beta are positive and more than 0.5 this indicated that there is a positive association between organizational culture with strategic success.

\subsubsection{Testing Third Research Hypothesis}

Table (15): Correlation analysis between competence and skills and strategic success

\begin{tabular}{|c|c|c|c|}
\hline \multicolumn{4}{|c|}{ Correlations } \\
\hline \multirow{2}{|c|}{} & $\begin{array}{c}\text { Employees } \\
\text { Skills and } \\
\text { Competences }\end{array}$ & Strategic Success \\
\hline \multirow{2}{*}{$\begin{array}{c}\text { Employees Skills and } \\
\text { Competences }\end{array}$} & Pearson Correlation & 1 & $.732^{* *}$ \\
\cline { 2 - 4 } & Sig.(2-tailed) & 168 & .000 \\
\cline { 2 - 4 } & $\mathrm{N}$ & $.732^{* *}$ & 168 \\
\hline \multirow{2}{*}{\begin{tabular}{c} 
Strategic Success \\
\cline { 2 - 4 }
\end{tabular}} & Pearson Correlation & .000 & 1 \\
\cline { 2 - 4 } & Sig.(2-tailed) & 168 & 168 \\
\cline { 2 - 4 } & $\mathrm{N}$ & \\
\hline$* *$ Correlation is significant at the 0.01 level (2-tailed).
\end{tabular}

Source: (By author, SPSS Version 23, 2021)

The table number (15) shows correlation analysis to measure the association between strategic success and competence and skills, it was found that there is a strong association between strategic success and competence and skills.

Table (16): Model Summary between competence and skills and strategic success

\begin{tabular}{|c|c|c|c|c|}
\hline \multicolumn{5}{|c|}{ Model Summary } \\
\hline Model & $\mathrm{R}$ & R Square & Adjusted R Square & Std. Error of the Estimate \\
\hline 1 & $.746 a$ & .678 & .671 & .2487 \\
\hline a. Predictors (Constant), Employees Skills and Competences \\
\hline
\end{tabular}

Source: (By author, SPSS Version 23, 2021)

The table (16) can be seen the value of $\mathrm{R}$ square is more than six hundred this means that more than $67 \%$ of factors have been demonstrated. 


\section{QALAAI ZANISTSCIENTIFIC JOURNAL}

A Scientific Quarterly Refereed Journal Issued by Lebanese French University - Erbil, Kurdistan, Iraq

Vol. (6), No (2), Spring 2021

ISSN 2518-6566 (Online) - ISSN 2518-6558 (Print)

Table (17): ANOVA between competence and skills and strategic success

\begin{tabular}{|c|c|c|c|c|c|c|}
\hline \multicolumn{7}{|c|}{ ANOVA } \\
\hline \multicolumn{2}{|r|}{ Mode } & Sum of & df & Mean & $\mathrm{F}$ & Sig. \\
\hline \multirow[t]{3}{*}{1} & Regression & 39.58 & 1 & 39.99 & 601.25 & $.000 \mathrm{~b}$ \\
\hline & Residual & 29.589 & 461 & .072 & & \\
\hline & Total & 73.56 & 459 & & & \\
\hline \multicolumn{7}{|c|}{ a. Dependent Variable: Strategic Success } \\
\hline \multicolumn{7}{|c|}{ b. Predictors (Constant), Employees Skills and Competences } \\
\hline
\end{tabular}

Source: (By author, SPSS Version 23, 2021)

The table (17) can be seen ANOVA analysis between skills and competences with strategic success. It was found that the value of $F$ was more than six hundred, this means that there is a strong association between skills and competences with strategic success.

Table (18): Simple regression analysis between competence and skills and strategic success

\begin{tabular}{|c|c|c|c|c|c|c|}
\hline \multicolumn{7}{|c|}{ Coefficients } \\
\hline & \multirow{2}{*}{ Model } & \multicolumn{2}{|c|}{$\begin{array}{l}\text { Unstandardized } \\
\text { Coefficients }\end{array}$} & \multirow{2}{*}{$\begin{array}{c}\text { Standardized } \\
\text { Coefficients } \\
\text { Beta } \\
\end{array}$} & \multirow[t]{2}{*}{$\mathrm{t}$} & \multirow[t]{2}{*}{ Sig. } \\
\hline & & $\mathrm{B}$ & Std. Error & & & \\
\hline \multirow[t]{2}{*}{1} & (Constant) & .088 & .263 & & .715 & .428 \\
\hline & $\begin{array}{c}\text { Competence } \\
\text { and Skills }\end{array}$ & 685 & .058 & .691 & 27.52 & .000 \\
\hline
\end{tabular}

Source: (By author, SPSS Version 23, 2021)

The table (18) can be seen regression between skills and competences with strategic success. As it can be seen in the above table the value of both $B$ and Beta are positive and more than 0.5 this indicated that there is a positive association between skills and competences with strategic success. 


\section{QALAAI ZANISTSCIENTIFIC JOURNAL}

A Scientific Quarterly Refereed Journal Issued by Lebanese French University - Erbil, Kurdistan, Iraq

Vol. (6), No (2), Spring 2021

ISSN 2518-6566 (Online) - ISSN 2518-6558 (Print)

\subsubsection{Testing Fourth Research Hypothesis}

Table (19): Correlation analysis between team cooperation and strategic success

\begin{tabular}{|c|c|c|c|}
\hline \multicolumn{4}{|c|}{ Correlations } \\
\hline \multirow{3}{*}{$\begin{array}{c}\text { Team } \\
\text { Cooperation }\end{array}$} & $\begin{array}{c}\text { Pearson } \\
\text { Correlation }\end{array}$ & Team Cooperation & Strategic Success \\
\cline { 2 - 4 } & Sig.(2-tailed) & 1 & $.786^{* *}$ \\
\cline { 2 - 4 } & $\mathrm{N}$ & 168 & .000 \\
\hline \multirow{2}{*}{ Strategic Success } & $\begin{array}{c}\text { Pearson } \\
\text { Correlation }\end{array}$ & $.786^{* *}$ & 168 \\
\cline { 2 - 4 } & Sig.(2-tailed) & .000 & 1 \\
\cline { 2 - 4 } & $\mathrm{N}$ & 168 & 168 \\
\hline$* *$ Correlation is significant at the 0.01 level (2-tailed). \\
\hline
\end{tabular}

Source: (By author, SPSS Version 23, 2021)

The table number (19) shows correlation analysis to measure the association between strategic success and team cooperation; it was found that there is a strong association between strategic success and team cooperation.

Table (20): Model summary between team cooperation and strategic success

\begin{tabular}{|c|c|c|c|c|}
\hline \multicolumn{5}{|c|}{ Model Summary } \\
\hline Model & $\mathrm{R}$ & R Square & Adjusted R Square & $\begin{array}{c}\text { Std. Error of the } \\
\text { Estimate }\end{array}$ \\
\hline 1 & .715 & .526 & .598 & .1895 \\
\hline \multicolumn{2}{|l}{} \\
\hline
\end{tabular}

Source: (By author, SPSS Version 23, 2021)

The table (20) can be seen, the value of $\mathrm{R}$ square is more than five hundred this means that more than $52 \%$ of factors have been demonstrated.

Table (21): ANOVA between team cooperation and strategic success

\begin{tabular}{|c|c|c|c|c|c|c|}
\hline \multicolumn{7}{|c|}{ ANOVA } \\
\hline \multicolumn{2}{|c|}{ Mode } & Sum of Squares & $\mathrm{df}$ & $\begin{array}{c}\text { Mean } \\
\text { Square }\end{array}$ & $\mathrm{F}$ & Sig. \\
\hline 1 & Regression & 39.58 & 1 & 39.96 & 452.52 & $.000 \mathrm{~b}$ \\
\hline
\end{tabular}




\section{QALAAI ZANISTSCIENTIFIC JOURNAL}

A Scientific Quarterly Refereed Journal Issued by Lebanese French University - Erbil, Kurdistan, Iraq

Vol. (6), No (2), Spring 2021

ISSN 2518-6566 (Online) - ISSN 2518-6558 (Print)

\begin{tabular}{|l|c|c|c|c|c|c|}
\hline & Residual & 27.658 & 298 & .091 & & \\
\cline { 2 - 7 } & Total & 29.568 & 299 & & & \\
\hline \\
a. Dependent Variable: Strategic Success \\
b. Predictors (Constant), Team Cooperation
\end{tabular}

Source: (By author, SPSS Version 23, 2021)

The table (21) can be seen ANOVA analysis between team cooperation with strategic success. It was found that the value of $F$ was more than six hundred, this means that there is a strong association between team cooperation with strategic success.

Table (22): Simple regression analysis between team cooperation and strategic success

\begin{tabular}{|c|c|c|c|c|c|c|}
\hline \multicolumn{7}{|c|}{ Coefficients } \\
\hline & \multirow[t]{2}{*}{ Model } & \multicolumn{2}{|c|}{$\begin{array}{l}\text { Unstandardized } \\
\text { Coefficients }\end{array}$} & \multirow{2}{*}{$\begin{array}{c}\text { Standardized } \\
\text { Coefficients } \\
\text { Beta }\end{array}$} & \multirow[t]{2}{*}{$\mathrm{t}$} & \multirow[t]{2}{*}{ Sig. } \\
\hline & & B & Std. Error & & & \\
\hline \multirow[t]{2}{*}{1} & (Constant) & .049 & .263 & & .379 & .639 \\
\hline & $\begin{array}{c}\text { Team } \\
\text { Cooperation }\end{array}$ & .701 & .052 & .719 & $\begin{array}{c}23.6 \\
1\end{array}$ & .000 \\
\hline
\end{tabular}

Source: (By author, SPSS Version 23, 2021)

The table (22) can be seen regression between team cooperation with strategic success. As it can be seen in the above table the value of both $B$ and Beta are positive and more than 0.5 this indicated that there is a positive association between team cooperation with strategic success. 


\section{Discussion}

The findings of this study indicate that organizational learning by joint project execution is required to establish long-term partnerships with stakeholders, which is value development in our analysis and considered a sufficient factor to sustain such a partnership; nevertheless, the explanation for this essential relationship could be beyond competent human capital. international funding for private universities in constitutionally insecure countries is necessary for sustainability. Furthermore, as other research has firmly advocated the value of constructing relative capital based on trust at the individual level between the knowledge-gaining parties, trust may play the most important role in the philosophy of such a partnership (Kale et al., 2000). Furthermore, value generation seems to be emulating the sustainable in an overwhelmingly negative way. Strategic performance in interconnection learning by collaborative ventures, when the essence of private universities' operations is heavily reliant on outside financing, also by third parties. Independent charities or civil society organizations that do not pay attention to the data. Partners are funded, but keeping in touch with them necessitates the growth of in-house capability with trained workers who can take a shorter path at local private universities. The legislative system seems to have a substantial effect on the available relation between planning studies and value creation; this fact can be seen directly in the landscape, where the availability of copies and legislation can create hesitation in private universities, potentially resulting in clashes in their favor. In recent decades, private universities have expanded dramatically, allowing them to develop a specialization in relief work and humanitarian problems in civil society around the world ( (Zhang \& Zhu, 2019). Domestic and domestic private universities in independent regions are taking more daunting directions, and the most pressing challenge facing private university boards in these difficult times is how to receive contributions in order to continue and expand. In addition to fighting for financial funds, private universities must negotiate and have a mission by displaying more programming work; however, how long they will withstand rivalry and compromise is unknown; as a result, private universities are often in conflict. To resolve this inconsistency, private universities must obtain long- 
term financing, just as the position of universities in private law may have the desired impact if it develops more systematic capacity-building policies for local private universities. People collaborate with multinational private universities and other agencies to strengthen humanitarian conditions in countries where conflict persists. Despite the normal procedures (Alomran, 2019), group civil society organizations, the participation of private universities in partnership pushes them to use more and new practices. To be ready for the evolutionary responses required by evolving environments, autonomous individuals must continually reinvent their organizational structure and operating processes. The number of private universities in the world is steadily increasing, and this growth is accompanied by the challenge of developing capabilities that are externally related to gaining confidence and responsibility from donors, sponsors, financial agencies, states, and partners, among others. developing capabilities that represent strengthening the capacity of staff to manage and perform organizational, financial, and administrative tasks (Annosi, et al., 2020). The growth of private universities in every area is not a bad thing, but the Private Universities Act's leniency traps can be described as abandoning the use of serious constructive requirements that might pull together state, national, and international private universities to best serve notified institutions. In developed and emerging countries, private universities have diverse social, political, educational, and economic backgrounds (Aspeling \& Mason, 2020). Despite differences in size, scope, scope, location, and climate, private universities across the world share shared principles, which include addressing humanitarian problems that arise from interactions between different actors. in a civil society field that connects north and south. The importance of private universities in the presentation of numerous facilities has been gradually recognized, but political science and international relations literature have examined their position in the formation of new protocols and treaties, as well as in their adjustment and progress. policies in various macro-policies, micro-policies, and norms. Deepen the stage fixes. The development of a global strategy for the engagement of private universities necessitates significant effort. 


\section{Conclusion}

In general, private colleges collaborate with society and assist one another on a number of issues. Learning is one of the most important topics for cooperation between private universities with different aims, particularly since the recent economic downturn, which has reduced many expectations of private universities as a way to retain funding and compete for scarce capital from various donors through competitive bids.

- This study is one of the empirical studies looking at the impact of collaborative knowledge - gained through the establishment of joint projects between local and national private universities based in autonomous regions and their international partners - on the development and maintenance of long-term relationships with international partners. Information convergence was shown to be strongly linked to strategic achievement, as was corporate culture, competences and capabilities, and team cooperation.

- It also looked into the impact of information sharing through joint ventures on the intentions of key individuals and seniors in private universities to discover new knowledge that is tailored to the current circumstances in autonomous regions under the control of various partners' knowledge bases.

- The lack of trained national capability creation providers capable of gaining the confidence of global supporters is seen as a major factor why many civil society organizations have struggled to secure long-term financial support. For example, civil society organizations and, more precisely, private universities have stressed the value of funding proposals as initial instruments for raising funds and better representing priorities, roles, personnel, national background, and much more in the literature. to draw sponsors, other supporting facts from private universities.

- Furthermore, political-legal circumstances and questions of legitimacy in constitutionally pluralistic regions have a bearing on private universities, potentially increasing trade risks and partner confidence issues. Credibility questions, the legal context under which private universities exist in 
independent societies, and the availability of dual roles and supervision, according to the empirical evidence presented by this report, have a substantial impact on preventing the interaction between interrelated research and learning. increase the partnership between inter-organizational learning and the intention of senior executives from private universities to explore expertise with their partners Furthermore, the findings of this study backed up the value of interrelationships between various partners based on experience in order to learn and gain new knowledge, as long as current partner conflicts are managed well.

\section{References}

Alomran, M. (2019). Implementation of strategic management practices in healthcare sector in Saudi Arabia. Int J Bus Adm Stud, 5(3), 131-144.

Annosi, M. C., Martini, A., Brunetta, F., \& Marchegiani, L. (2020). Learning in an agile setting: A multilevel research study on the evolution of organizational routines. Journal of Business Research, 110, 554-566.

Aspeling, J. M., \& Mason, R. B. (2020). Towards an E-Learning Support Strategy for the Retail Sector in South Africa. International Journal of Web-Based Learning and Teaching Technologies (IJWLTT), 15(3), 1-18.

Bahrami, M. A., Kiani, M. M., Montazeralfaraj, R., Zadeh, H. F., \& Zadeh, M. M. (2016). The mediating role of organizational learning in the relationship of organizational intelligence and organizational agility. Osong public health and research perspectives, 7(3), 190-196.

Birasnav, M., Chaudhary, R., \& Scillitoe, J. (2019). Integration of social capital and organizational learning theories to improve operational Strategic success. Global Journal of Flexible Systems Management, 20(2), 141-155.

Bratnicki, M., \& Dyduch, W. (2020). Understanding Cognitive Biases in Strategic Decisions for Value Creation and Capture. In Contemporary Challenges in Cooperation and Coopetition in the Age of Industry 4.0 (pp. 359-373). Springer, Cham. 


\section{QALAAI ZANISTSCIENTIFIC JOURNAL \\ A Scientific Quarterly Refereed Journal Issued by Lebanese French University - Erbil, Kurdistan, Iraq \\ Vol. (6), No (2), Spring 2021 \\ ISSN 2518-6566 (Online) - ISSN 2518-6558 (Print)}

Chen, K. H., Wang, J. S., Lin, M. H., \& Chang, W. Y. (2018). The influence of learning organization on organizational innovation and organizational Strategic success relationship: The Case of Ecology Industry. Ekoloji, 27(106), 329-335.

Chepsergon, J., Motaung, T. E., Bellieny-Rabelo, D., \& Moleleki, L. N. (2020). Organize, Don't Agonize: Strategic Success of Phytophthora Species. Microorganisms, 8(6), 917.

Colman, H. L. (2020). Facilitating integration and maintaining autonomy: The role of managerial action and interaction in post-acquisition cabability transfer. Journal of Business Research, 109, 148-160.

Danish, M. S. S., Elsayed, M. E. L., Ahmadi, M., Senjyu, T., Karimy, H., \& Zaheb, H. (2020). A strategic-integrated approach for sustainable energy deployment. Energy Reports, 6, 40-44.

Ejodame, K., \& Oshri, I. (2018). Understanding knowledge re-integration in backsourcing. Journal of Information Technology, 33(2), 136-150.

Eniola, A. A., Olorunleke, G. K., Akintimehin, O. O., Ojeka, J. D., \& Oyetunji, B. (2019). The impact of organizational culture on total quality management in SMEs in Nigeria. Heliyon, 5(8), e02293.

Gauriot, R., \& Page, L. (2019). Does success breed success? A quasi-experiment on strategic momentum in dynamic contests. The Economic Journal, 129(624), 3107-3136.

Hagemeister, M., \& Rodríguez-Castellanos, A. (2019). Knowledge acquisition, training, and the firm's Strategic success : A theoretical model of the role of knowledge integration and knowledge options. European Research on Management and Business Economics, 25(2), 48-53.

Husain, Z., Dayan, M., \& Di Benedetto, C. A. (2016). The impact of networking on competitiveness via organizational learning, employee innovativeness, and innovation process: A mediation model. Journal of Engineering and Technology Management, 40, $15-28$.

Kasuganti, A. R. (2017). Organizational Learning: The Role of the Physical Environment. Psychological Studies, 62(4), 357-369.

Knein, E., Greven, A., Bendig, D., \& Brettel, M. (2020). Culture and cross-functional coopetition: The interplay of organizational and national culture. Journal of International Management, 26(2), 100731. 


\section{QALAAI ZANISTSCIENTIFIC JOURNAL \\ A Scientific Quarterly Refereed Journal Issued by Lebanese French University - Erbil, Kurdistan, Iraq}

Vol. (6), No (2), Spring 2021

ISSN 2518-6566 (Online) - ISSN 2518-6558 (Print)

Lin, C. Y., Huang, C. K., \& Zhang, H. (2019). Enhancing employee job satisfaction via E-learning: the mediating role of an organizational learning culture. International Journal of Human-Computer Interaction, 35(7), 584-595.

Martinsuo, M. (2019). Strategic value at the front end of a radical innovation program. Project Management Journal, 50(4), 431-446.

Morcillo-Bellido, J. (2019). Strategic alliance trends in the Spanish food and beverage industry. IUP Journal of Supply Chain Management, 16(1), 22-36.

Pabico, C., Perkins, C. K., Graebe, J., \& Cosme, S. (2019). Creating a culture of lifelong learning: A strategy for organizational success. Nursing management, 50(2), 9-11.

Pillai, S. D., Goldfarb, B., \& Kirsch, D. A. (2020). The origins of firm strategy: Learning by economic experimentation and strategic pivots in the early automobile industry. Strategic Management Journal, 41(3), 369-399.

Prasetya, A. B. (2017). Organizational Lerning and Strategy: Information Processing Approach of Organizaitonal Learning to Perform Strategic Choice Analysis. The Winners, 18(1), 25-32.

Ruy, M., \& Alliprandini, D. H. (2017). Organizational learning in the context of product development management. Product: Management and Development, 3(2), 133-145.

Schniederjans, D. G., Curado, C., \& Khalajhedayati, M. (2020). Supply chain digitisation trends: An integration of knowledge management. International Journal of Production Economics, 220, 107439.

Shahar, S. M., Ma'arif, M. Y., Yusof, M. F. H., \& Satar, N. S. M. (2019, September). Research Methodology Trending in Evolutionary Computing. In International Conference on Computational Collective Intelligence (pp. 474-485). Springer, Cham.

Valdez-Juárez, L. E., Gallardo-Vázquez, D., \& Ramos-Escobar, E. A. (2019). Organizational Learning and Corporate Social Responsibility Drivers of Performance in SMEs in Northwestern Mexico. Sustainability, 11(20), 5655.

Wang, J., Feng, X., Xu, T., Ning, H., \& Qiu, T. (2020). Blockchain-Based Model for Nondeterministic Crowdsensing Strategy With Vehicular Team Cooperation. IEEE Internet of Things Journal, 7(9), 8090-8098. 


\section{QALAAI ZANISTSCIENTIFIC JOURNAL \\ A Scientific Quarterly Refereed Journal Issued by Lebanese French University - Erbil, Kurdistan, Iraq}

Vol. (6), No (2), Spring 2021

ISSN 2518-6566 (Online) - ISSN 2518-6558 (Print)

Waqas, M., Rehman, C. A., Ullah, P. S., \& Nizami, M. A. N. (2019). Relationship of Organizational Learning and Perceived Firm Performance Through Lenses of Low-Cost Price Strategy. Paradigms, 13(1), 111-116.

Zhang, F., \& Zhu, L. (2019). Enhancing corporate sustainable development: Stakeholder pressures, organizational learning, and green innovation. Business Strategy and the Environment, 28(6), 1012-1026.

\section{رِيّكخراوى فيّربوون و كاريكهرى لهسهر سهركهوتنى ستراتيزى : شيكردنهومى دامهزراوه تايبهتهكانى خويّندنى بالاّى ههوليّر}

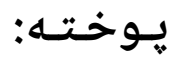

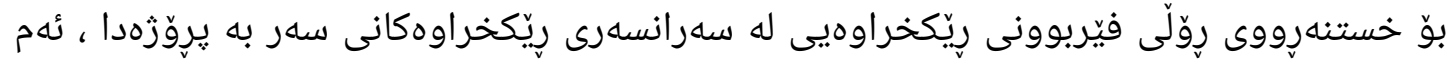

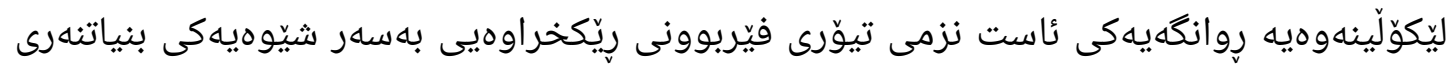

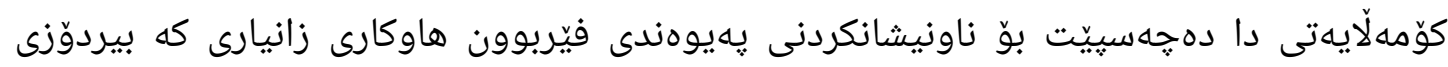

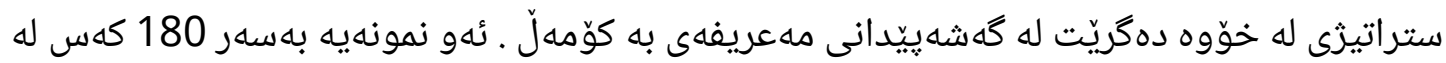

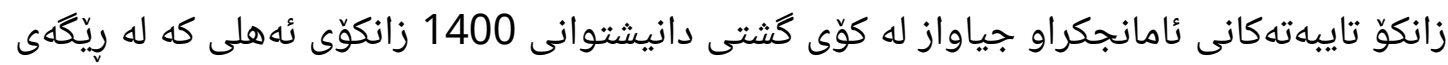

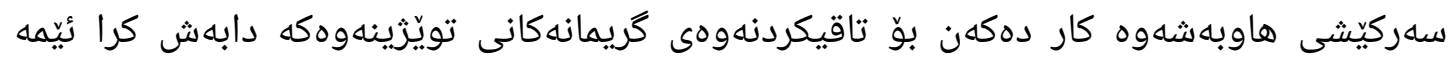

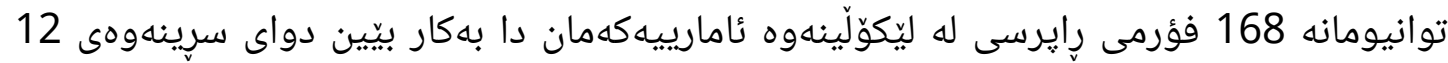

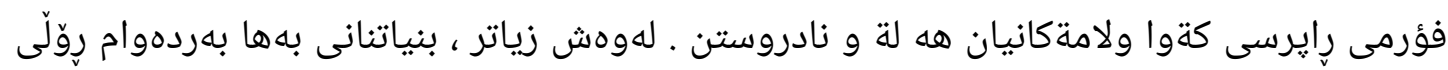

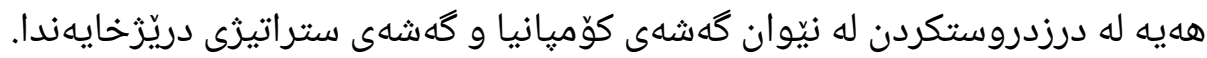

ههروهها، ئامانجى كهرانى يووركارى يى كارى نيّوهندسازى گهوره له فيّربوونى نيّو ريّكخراوهيى دا

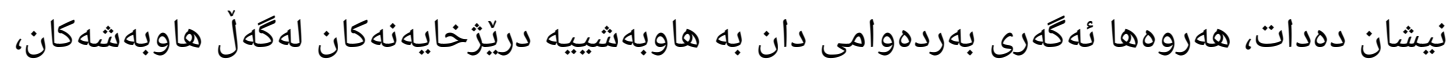
وهك ئهنجاميّكى سووددهرى جياوازى هاوبهش وهك فاكتهريّكى مامناوهند. لِيكجوونى زانيارى نيشان درا كه به توندى به دهستكهوتى ستراتيزيهوه بهسترابيّت، وهك ئهوهى كه جاند و توانست و توانستى هاوبهش و هاوكاريى تيمهكان بوو. 


\section{QALAAI ZANISTSCIENTIFIC JOURNAL}

A Scientific Quarterly Refereed Journal Issued by Lebanese French University - Erbil, Kurdistan, Iraq

Vol. (6), No (2), Spring 2021

ISSN 2518-6566 (Online) - ISSN 2518-6558 (Print)

منظمة التعلم وأثرها في النجاح الاستراتيجي: تحليل مؤسسات التعليم العالي الخاصة في أربيل ن ناتجيل

لإثبات دور التعلم التنظيمي عبر المنظمات القائمة على المشاريع، يستخدم هذا البحث منظور المستوى الجزئي

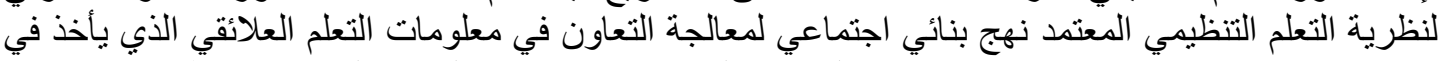

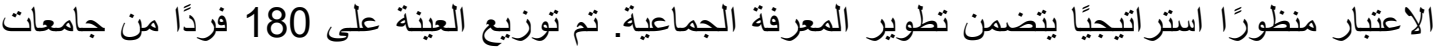

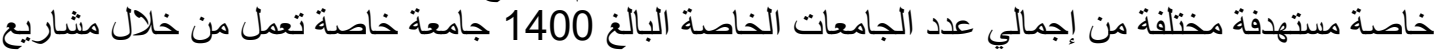
تعاونية لاختبار فرضيات البحث. استخدمنا 168 استبيانا من مجموع الاستمار ات المسترجعة وذلك بعد استبعاد 12 منها وذللك بسبب كون نتائجها وإجاباتها غير صحيحة. يُظهر الغرض فئ الاستكثافي من وظيفة الوساطة

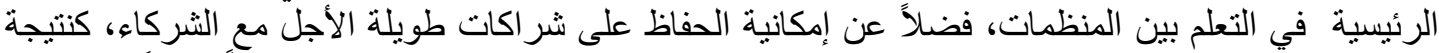

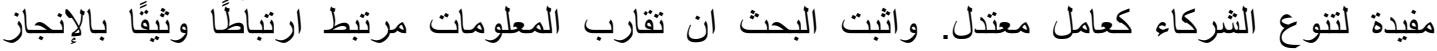

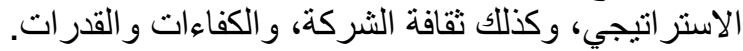

مفاتيح الكلمات : التعلم التنظيمي، إدارة المعرفة، تكامل المعرفة، التعاون الجماعي ، الجامعات الخاصة 